Anronson, S. (1956). J. gen. Microbiol. 15, 478-484

\title{
A Biochemical-taxonomic Study of a Marine Micrococcus, Gaffkya homari, and a Terrestrial Counterpart
}

\author{
By S. AARONSON \\ Haskins Laboratories and the Biology Department, \\ Queens College, New York, N.Y., U.S.A.
}

SUMMARY: The morphology, minimal nutritional requirements, and biochemical reactions of the lobster pathogen, Gaffkya homari, and of a tetracoccus found contaminating meat products were compared. The marine and terrestrial cocci were identical by the in vitro methods used. The validity of the genus Gaffkya is discussed. The 4 strains of micrococci herein studied had an unusual nitrogen requirement: all required glutamic acid as nitrogen source; substrates were not utilized in the absence of glutamate.

Snieszko \& Taylor (1947) described a Gram-positive, tetrad-forming micrococcus from septicaemic lobsters and called it Gaffkya homari. W. S. Sturges (1950, personal communication) isolated Gram-positive, tetrad-forming micrococci as occasional contaminants of meat products in a mid-western United States meat-packing plant. In the present study two strains each of the marine tetracoccus and of the terrestrial tetracoccus, were examined biochemically and morphologically. No clear differences were detected between them. This uniformity made it necessary to examine the criteria used to define the genus Gaffkya.

\section{METHODS}

Organisms. Gaffkya homari (ATCC 10400) was obtained from the American Type Culture Collection; G. homari RT-4 was obtained from Dr J. S. Getchell, Agricultural Experiment Station, Orono, Maine. The terrestrial tetrad-forming micrococci strain S-1 was isolated from the exposed cut surface of bologna sausage and strain S-5 was isolated from a discoloured area of meat, and were obtained through the courtesy of Dr W. S. Sturges, Cudahy Packing Co., Omaha, Nebraska. G. tetragena (ATCC 159) was obtained from Mr S. A. Rosenthal, Department of Bacteriology, University of Maine, Orono, Maine. Micrococcus sodonensis was obtained from Dr A. Bicknell, Michigan State College, East Lansing, Michigan; Sarcina lutea from Dr J. Webb, Biology Department, City College, New York, N.Y.; Staphylococcus flavocyaneus from the National Collection of Type Cultures (NCTC 7011).

The culture methods and the measurement of growth were essentially those used by Baker, Sobotka \& Hutner (1953). Cultures were usually incubated at 35-37 ${ }^{\circ}$ for 5-7 days. Stock cultures were maintained on a medium described by Aaronson (1955). All chemicals were obtained from commercial sources.

Diagnostic tests for the identification of micrococci were those recommended in the Manual of Methods published by the Society of American Bacteriologists. 


\section{RESULTS}

Morphology. These marine and terrestrial micrococci are Gram-positive, non-motile, c. 0.8-1.0 $\mu$. diam., and form tetrads; their form is unchanged after several years on artificial media. On agar slopes and plates they grow as minute greyish white raised colonies $(c .1 .0 \mathrm{~mm}$. diam.) with rough surfaces and entire edges. They usually appear as beads rather than streaks or sheets on slopes; the rapid formation of acid may prevent confluent growth. In a chemically defined medium buffered with $0.5 \%$ glutamic acid $+0.5 \%$ Tris(hydroxymethyl)-aminomethane and initially at $\mathrm{pH} 8 \cdot 7$, the $\mathrm{pH}$ value will be lowered below $5 \cdot 0$ by 5 days of growth

Diagnostic biochemical reactions. All 4 strains gave the same diagnostic reactions by the tests used (Table 1). For comparison the reactions of other cocci are included (see also Table 2).

Response to antibiotics. As noted in Table 2, the differences between Gaffkya homari ATCC 10400 and S-1 were minor as compared with the difference between these organisms and the other cocci.

Minimal nutritional requirements. All 4 strains grew well in a chemically defined medium (Table 3). Final growth, however, was stimulated as much as $20 \%$ after the addition of a mixture of amino acids (Table 4).

Sucrose, glycerol, glucose or gluconate served as both carbon and energy source, provided that a small amount of glutamic acid (c. $0.1 \%, w / v)$ was present. Fumarate, succinate, lactate, citrate, acetate, glycine, L-glutamate, DL-aspartate, DL-asparagine, and DL-alanine did not support growth even with added glutamic acid.

Sulphate satisfied the sulphur requirement. In a defined medium the optimal pH was 8.7 (the highest $\mathrm{pH}$ value tested). The optimum temperature for growth was $c .3^{\circ}$.

Nitrogen requirement. All 4 strains had an absolute requirement for glutamic acid; it was not adequate as the sole source of energy, carbon and nitrogen but supported growth on the addition of suitable carbon and energy sources. Attempts to replace the glutamate with $\mathrm{NH}_{4} \mathrm{Cl}, \mathrm{KNO}_{2}, \mathrm{KNO}_{3}$, glycine, DLalanine, DL-aspartate, DL-asparagine, and L-glutamine (added aseptically), each at several concentrations within the range $0 \cdot 05-1 \cdot 0 \%(w / v)$ failed.

Osmotic and salt tolerances. All 4 strains were similar in their responses to increasing osmotic pressure and increasing salt concentration (Table 5). Pentaerythritol did not inhibit any of the 4 strains in the concentration range used $(1 \cdot 0-10 \cdot 0 \%)$.

\section{DISCUSSION}

Comparison of marine and terrigenous strains. The consistent similarities noted here argue that the strains should all be denoted as Gaffkya homari despite their diverse origins. The occurrence of related or identical species of bacteria in the sea and on the land has previously been noted (Wood, 1952; ZoBell, 1946). The marine and terrestrial environments of the cocci herein studied may be much alike in respect to osmotic pressure and high 
Table 1. Diagnostic biochemical reactions of Gaffkya homari strains and other cocci

\begin{tabular}{|c|c|c|c|c|c|c|}
\hline \multirow[b]{2}{*}{ Strains } & \multirow[b]{2}{*}{$\cdots$} & \multirow[b]{2}{*}{$\cdots$} & \multicolumn{2}{|c|}{ G. homari } & \multicolumn{2}{|c|}{ Terrestrial strains } \\
\hline & & & ATCC 10400 & RT-4 & S-1 & S-5 \\
\hline \multirow{3}{*}{\multicolumn{3}{|c|}{$\begin{array}{l}\text { Arabinose } \\
\text { Dulcitol } \\
\text { Glucose }\end{array}$}} & Acid & Acid & Acid & Acid \\
\hline & & & n.c. & n.c. & n.c. & n.c. \\
\hline & & & Acid & Acid & Acid & Acid \\
\hline \multirow{2}{*}{\multicolumn{3}{|c|}{$\begin{array}{l}\text { Inositol } \\
\text { Lactose }\end{array}$}} & n.c. & n.c. & n.c. & n.c. \\
\hline & & & Acid & Acid & Acid & Acid \\
\hline \multicolumn{3}{|l|}{ Maltose } & Acid & Acid & Acid & Acid \\
\hline \multicolumn{3}{|l|}{ Mannitol } & Acid & Acid & Acid & Acid \\
\hline \multicolumn{3}{|l|}{ Sucrose } & Acid & Acid & Acid & Acid \\
\hline \multicolumn{3}{|c|}{ Xylose } & n.c. & n.c. & n.c. & n.c. \\
\hline \multicolumn{3}{|c|}{ Tryptone broth (indole) } & n.c. & n.c. & n.c. & n.c. \\
\hline \multicolumn{3}{|c|}{ Starch hydrolysis } & n.c. & n.c. & n.c. & n.c. \\
\hline \multicolumn{3}{|c|}{ Gelatin hydrolysis } & n.c. & n.c. & n.c. & n.c. \\
\hline \multicolumn{3}{|c|}{ Litmus milk } & n.c. & n.c. & n.c. & n.c. \\
\hline \multicolumn{3}{|c|}{$\begin{array}{l}\mathrm{NO}_{3} \text { reduced to } \mathrm{NO}_{2} \\
\text { Urea broth }\end{array}$} & n.c. & n.c. & n.c. & n.c. \\
\hline Urea bro & & & n.c. & n.c. & n.c. & n.c. \\
\hline \multicolumn{3}{|c|}{ Citrate broth } & n.c. & n.c. & n.c. & n.c \\
\hline Strains & $\cdots$ & $\cdots$ & $\begin{array}{l}\text { G. tetragena } \\
\text { ATCC } 159\end{array}$ & $\begin{array}{c}\text { Micrococcus } \\
\text { sodonensis }\end{array}$ & $\begin{array}{c}\text { Sarcina } \\
\text { lutea }\end{array}$ & $\begin{array}{l}\text { Staphylococcus } \\
\text { flavocyäneus }\end{array}$ \\
\hline \multirow{2}{*}{\multicolumn{3}{|c|}{$\begin{array}{l}\text { Arabinose } \\
\text { Dulcitol }\end{array}$}} & n.t. & n.t. & n.t. & n.t. \\
\hline \multirow{2}{*}{\multicolumn{3}{|c|}{ Glucose }} & n.t. & n.t. & n.t. & n.t. \\
\hline & & & n.c. & n.c. & n.c. & n.c. \\
\hline \multicolumn{3}{|l|}{ Inositol } & n.t. & n.t. & n.t. & n.t. \\
\hline \multicolumn{3}{|l|}{ Lactose } & n.c. & n.c. & n.c. & n.c. \\
\hline \multicolumn{3}{|l|}{ Maltose } & n.c. & n.c. & n.c. & n.c. \\
\hline \multicolumn{3}{|l|}{ Mannitol } & n.c. & n.c. & n.c. & n.c. \\
\hline \multicolumn{3}{|l|}{ Sucrose } & n.c. & n.c. & n.c. & n.c. \\
\hline \multicolumn{3}{|l|}{ Xylose } & n.t. & n.t. & n.t. & n.t. \\
\hline \multicolumn{3}{|l|}{ Indole } & n.c. & n.c. & n.c. & n.c. \\
\hline \multicolumn{3}{|l|}{ Starch } & n.c. & n.c. & n.c. & n.t. \\
\hline Gelatin & & & + & n.c. & + & + \\
\hline Litmus n & & & Basic & n.c. & Basic & n.t. \\
\hline $\mathrm{NO}_{3} \rightarrow \mathrm{NC}$ & & & + & n.c. & n.c. & n.c. \\
\hline Urea bro & & & n.t. & n.t. & n.t. & n.t. \\
\hline Citrate b & & & + & + & n.c. & n.c. . \\
\hline
\end{tabular}

n.c. $=$ no change $;$ n.t. $=$ not tested; $+=$ growth or change in medium .

Table 2. Sensitivity of cocci to several antibiotics

The organisms were grown on nutrient agar.

$$
\begin{array}{ccccc}
\text { G. homari } & \multicolumn{3}{c}{\text { G. tetragena }} \\
\text { ATCC } & \text { G. homari } & \text { ATCC } & \text { Micrococcus } & \text { Staphylococcus Sarcina } \\
10400 & \text { S-1 } & 159 & \text { sodonensis flavocyaneus lutea }
\end{array}
$$

\begin{tabular}{|c|c|c|c|c|c|c|}
\hline $\begin{array}{l}\text { Streptomycin, } \\
\text { c. } 500 \text { units/disk }\end{array}$ & $2 \cdot 9$ & $2 \cdot 7$ & $4 \cdot 1$ & $\mathbf{3} \cdot \mathbf{3}$ & $4 \cdot 3$ & 4.5 \\
\hline $\begin{array}{l}\text { Penicillin G, } \\
\text { c. } 500 \text { units/disk }\end{array}$ & 4.3 & $3 \cdot 7$ & $5 \cdot 1$ & $5 \cdot 0$ & $6 \cdot 2$ & 6.0 \\
\hline $\begin{array}{l}\text { Aureomycin, } \\
\text { c. } 250 \mu \mathrm{g} . / \text { disk }\end{array}$ & $3 \cdot 5$ & $3 \cdot 6$ & $\mathbf{3} \cdot \mathbf{2}$ & $2 \cdot 2$ & 4.4 & $4 \cdot 1$ \\
\hline $\begin{array}{l}\text { Polymyxin, } \\
\text { c. } 500 \text { units/disk }\end{array}$ & 1.0 & 0.9 & 1.0 & $1 \cdot 1$ & $I \cdot 1$ & $1 \cdot 3$ \\
\hline
\end{tabular}

Inhibition zone diameter (cm.) average of two experiments 
Table 3. Defined medium for strains of Gaffkya homari

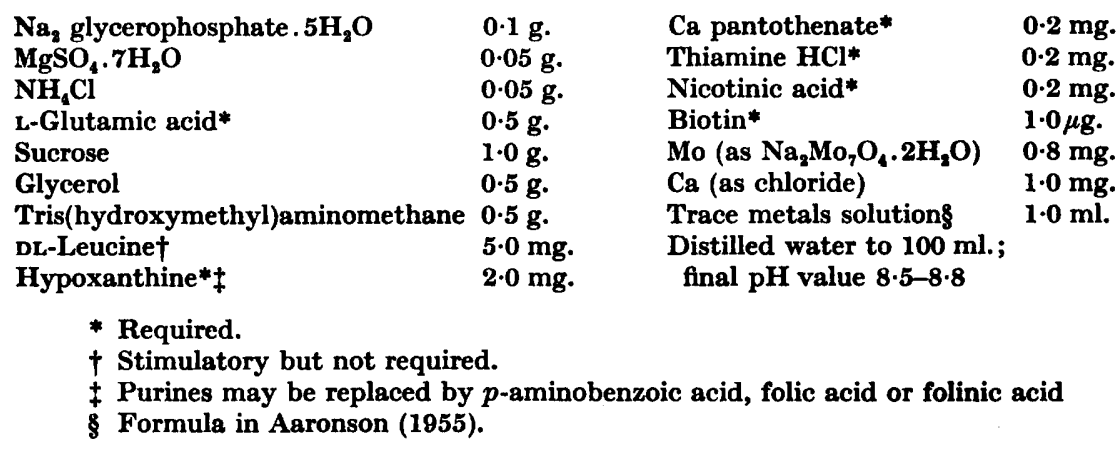

Table 4. Amino acid supplement which stimulated growth when added to the defined medium of Table $\mathbf{3}$

$\begin{array}{lllc} & \text { g. } & & \mathrm{g} . \\ \text { DL-Alanine } & 0.04 & \text { DL-Methionine } & \mathbf{0 . 0 0 6} \\ \text { L-Arginine (free base) } & 0.03 & \text { DL-Phenylalanine } & \mathbf{0 . 0 0 4} \\ \text { DL-Aspartic acid } & 0.05 & \text { L-Proline } & 0.004 \\ \text { L-Glutamic acid } & 0 \cdot 1 & \text { DL-Serine } & 0.01 \\ \text { Glycine } & 0.05 & \text { DL-Threonine } & 0.01 \\ \text { L-Histidine (free base) } & 0.02 & \text { DL-Tryptophan } & 0.005 \\ \text { DL-Isoleucine } & 0.005 & \text { L-Tyrosine } & 0.004 \\ \text { DL-Leucine } & 0.005 & \text { DL-Valine } & 0.005 \\ \text { DL-Lysine HCl } & 0.045 & \text { Distilled water to } 100 \mathrm{ml} . ; & \\ & & \text { final pH value 6.5. }\end{array}$

Table 5. Effect of osmotic pressure and salt concentration on strains of Gaffkya homari grown on a chemically defined medium. See Table $\mathbf{3}$

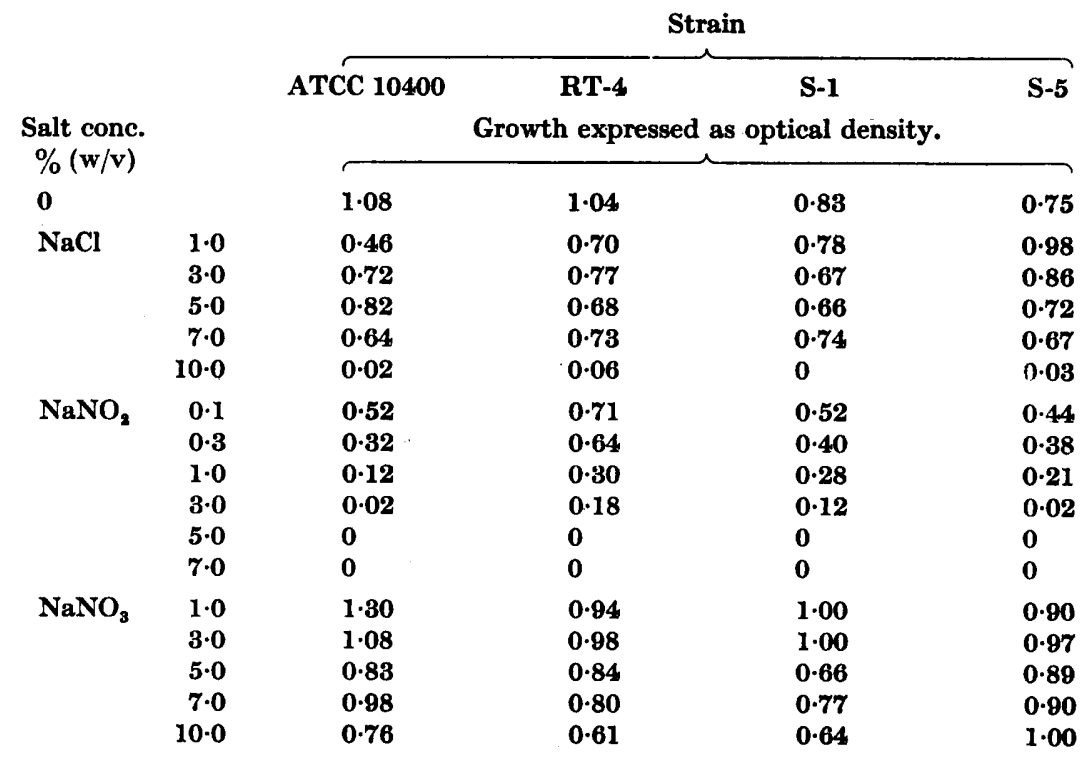


concentrations of electrolytes and of organic compounds. These environmental similarities may account for the success in isolating similar strains. It would be of interest to know whether the strains isolated from meat products can cause septicaemia in lobsters.

Glutamic acid as an obligate nitrogen source. The strains studied have a requirement for glutamic acid as a nitrogen source which is neither spared or replaced by any of the nitrogen-containing compounds tested. Gilvarg \& Davis (1954) reported an obligate glutamate requirement for an Escherichia coli mutant. Wiame \& Storck (1953) reported that glutamate would serve as the sole nitrogen source for certain Bacillus subtilis mutants; several amino acids replaced the glutamate. As experiments with $\alpha$-ketoglutarate were not tried with Gafflya homari strains, it is not clear whether or not the specificity of this requirement resides in the carbon skeleton.

Critiquie of the genus Gaffkya. As defined by Bergey's Manual (1948) Gaffkya strains '...occur in animal body and in special media as tetrads, while in ordinary culture media they occur in pairs and irregular masses. Aerobic to anaerobic. Gram positive. Parasitic organisms.' The lobster pathogen fits this genus since it is a tetrad-forming Gram-positive coccus and a parasite. Parasitism seems to be an important-even essential-criterion for assigning a coccus to Gaffkya. If one followed Bergey's Manual, the saprophytic strains S-1 and S-5 would be excluded from Gaffkya. The strains S-1 and S-5 are nutritionally, biochemically and morphologically identical with the strains of Gaffkya homari by all the in vitro methods here used; these strains must be assigned to $G$. homari if the criterion of parasitism be abandoned.

The nomenclatural vicissitudes of the genus Gaffkya attest to the inadequacy of its definition. It was created by Trevisan (1885) for the tetrad coccus isolated by Gaffky (1883) and called by him Micrococcus tetragenus. The Winslows (1908) placed this species in the genus Albococcus with the white staphylococci. Buchanan (1917) placed it in Staphylococcus, Hucker (1924a, 1928) and Fleming (1929) in Micrococcus; and Bergey's Manual (1930) returned it to Gaffkya. Lehmann \& Neumann (1931) placed it in Sarcina, but succeeding editions of Bergey's Manual retained Gaffkya as a genus. Wood (1950), Shaw, Stitt \& Cowan (1951) and Bisset (1952) advocated the elimination of Gaffkya because of the close similarity of these bacteria to other micrococci with which they intergrade. It would appear from the present study that the criteria used to distinguish the genus in Bergey's Manual, especially parasitism, are dubious; the genus may have to be dismantled and its component species distributed elsewhere, e.g. G. tetragena may have to be placed in Staphylococcus (Micrococcus) occupying a position alongside $S$. albus, with which it shares colonial morphology, habitat, and antigens (Hucker, 1924b, Hucker \& Robertson, 1926). G. tetragena and $G$. homari share tetrad-formation and parasitism, but they may not otherwise be closely related. They differ morphologically (tetragena cells are larger and colonial and slope growth is more abundant) and biochemically (tetragena does not ferment carbohydrates or milk and does reduce nitrate to ammonia; Bergey's Manual; Snieszko \& Taylor, 1947) and they have no common agglutinogens (Rosenthal, 1950). Shaw et al. (1951) 
described cocci ('group iii') which they placed among the staphylococci to which $G$. homari shows some resemblance; unfortunately their description does not permit detailed comparison.

The good agreement between the biochemical reactions and the morphological criteria currently used in bacterial taxonomy and the additional information on growth factors, carbon, nitrogen, and sulphur sources, and effects of chemical agents, including antibiotics, seen in these studies suggest that biochemical criteria may well complement the older taxonomic criteria.

I wish to thank Professor R. F. Nigrelli of New York University for his support and encouragement and Professor E. R. Hitchner of the University of Maine for his aid in obtaining some of the bacterial strains used and for stimulating discussions on the biology of the lobster infection.

\section{REFERENCES}

Aaronson, S. (1955). The purine requirement of Staphylococcus flavocyaneus. J. gen. Microbiol. 12, 147.

Baker, H., Sobotka, H. \& Hutner, S. H. (1953). Growth requirements of some thermophilic and mesophilic bacilli. J. gen. Microbiol. 9, 485.

Bergey's Manual of Determinative Bacteriology (1930). 3rd edition, edited by Breed, R. S., Murray, E. G. D. \& Hitchens, A. P. Baltimore: Williams and Wilkins Co.

Bergey's Manual of Determinative Bacteriology (1948). 6th edition, edited by Breed, R. S., Murray, E. G. D. \& Hitchens, A. P. Baltimore: Williams and Wilkins Co.

Bisset, K. A. (1952). Bacteria. Baltimore: Williams and Wilkins Co.

Buchanan, R. E. (1917). Studies in the nomenclature and classification of bacteria. IV. Subgroups and genera of the Coccaceae. J. Bact. 2, 603.

Fleming, A. (1929). A System of Bacteriology in Relation to Medicne, vol. rr, chap.1. London: His Majesty's Stationery Office.

GafFKy, G. (1883). Über antiseptische Eigenschaften des in der Esmarckschen Klinik als Verlandmittel benutzen Tormills. Arch. klin. Chir. 28, 495.

Gilvarg, C. \& Davis, B. D. (1954). Significance of the tricarboxylic acid cycle in Escherichia coli. Fed. Proc. 13, 217.

Hucker, G. J. (1924a). Studies on the Coccaceae. II. A study of the general characters of the micrococci. Tech. Bull. N.Y. St. agric. Exp. Sta. no. 100.

Hucker, G. J. (1924b). Studies on the Coccaceae. IV. The classification of the genus Micrococcus Cohn. Tech. Bull. N.Y. St. agric. Exp. Sta. no. 102.

Hucker, G. J. (1928). Studies on the Coccaceae. IX. Further studies on the classification of the micrococci. Tech. Bull. N.Y. St. agric. Exp. Sta. no. 135.

Hucker, G. J. \& Robertson, A. H. (1926). Studies on the Coccaceae. VI. The agglutination reaction as a test for differentiating the micrococci. Tech. Bull. N.Y. St. agric. Exp. Sta. no. 118.

Lehmann, K. B. \& Neumann, R. O. (1931). Atlas and Essentials of Bacteriology, vol. I. Transl. by R. S. Breed et al.; N.Y.: G. E. Stechert and Co.

Rosenthal, S. A. (1950). Serological Studies of Strains of Gaffkya homari. M.Sc. Thesis, University of Maine, Orono.

Shaw, C., StitT, J. M. \& Cowan, S. T. (1951). Staphylococci and their classification. J. gen. Microbiol. 5, 1010.

Snieszko, S. F. \& Taylor, C. C. (1947). A bacterial disease of the lobster (Homarus americanus). Science, 105, 500.

Trevisan, V. (1885). Caratteri di alcuni nuovi generi di batteriacea. Atti Accad. Fisio-Medico-Statistica, Milano, 3, 92. 
Wiame, J. M. \& Storck, R. (1953). Metabolisme de l'acide glutamique chez Bacillus subtilis. Biochim. biophys. Acta, 10, 268.

Winslow, C.-E. A. \& Winslow, A. R. (1908). The Systematic Relationships of the Coccaceae. N.Y.: John Wiley and Sons.

Wood, E. J. F. (1950). The classification of bacteria with special reference to nonpathogenic Eubacteria. Proc. Linn. Soc. N.S.W. 75, 158.

Wood, E. J. F. (1952). The micrococci in a marine environment. J.gen. Microbiol. 6, 205.

ZoBer., C. E. (1946). Marine Microbiology. Waltham, Mass. : Chronica Botanica Co.

(Received 9 May 1956) 